\title{
APPLICATOIN OF THE PRINCIPLE OF TRUST IN THE LAND REGIS- TRY IN THE CONTEXT OF THE DISPOSITION OF MARITAL ASSETS
}

\section{Hamid Mutapčić1 Esad Oruč}

Faculty of Law, University of Tuzla International Burch University

Received: 28.10 .2016

Accepted: 24.12.2016
Original scientific paper

DOI: $10.21554 / \mathrm{hrr} .041701$

\begin{abstract}
By entering into effect of the new Entity laws on the land registry, a new definition of the principle of trust is introduced, a definition that aims at the protection of the rights that have been acquired on the basis of incorrect or incomplete land registry status. However, the question arises of whether the third conscientious person will have any protection regarding the acquisition of property rights on real estate that is a part of marital assets, when such real estate is recorded in the land registry only belonging to one marital partner. In the legal theory and jurisprudence the issue of validity of the legal relation regarding the sale and the burdening of such real estate by the registered right holder has been raised. Bearing in mind the fact that in our legal system the principle of causal tradition is applied, coming to the correct position on this legal issue is very significant. Further scientific research in this area is of particular importance due to the ongoing process of the reform of land registry law, whose purpose is the reaffirmation of the land registry and the creation of legal presumptions for a faster and simpler legal disposition of real estate.
\end{abstract}

Key words: principle of trust in the land registry, principle of conscientiousness, marital assets

\section{INTRODUCTION}

For a long time now the land registries in Bosnia and Herzegovina do not have the significance that they used to have under the Law on land registry of the Kingdom of Yugoslavia (in the remainder of the text: ZZK KJ). In the legal existence there exists a large disparity between the on the land registry record and off the record state of real estate. A small number of persons go through the registration of their acquired rights in the land registry. The most frequent reasons for not registering ones rights is the avoidance of tax implications, lack of due diligence or care and low awareness of the significance of such acts that exists in certain social environs. The consequence of this is the existence of incorrect (untrue) and incomplete status of the land registry, as the persons who are registered as right holders are not the true owners of the real estate, or rather in the land registry the rights that exist off the record have not been recorded as a burden or a limitation regarding a particular piece of real estate.

After the land registry had in a large part lost the significance of an accurate and complete record of real estates and the rights on said real estate, what followed was a determined intent of the Legislator to end such a legal tradition and to ensure the legal presumption for a successful functioning of the land register and safe legal transactions in real estate. By coming into power of the new entity laws on land registries (in the remainder of the text $\mathrm{ZZK} \mathrm{FBiH} /$ RS) the reform of real estate law had begun.

\footnotetext{
${ }^{1}$ Correspondence to:

Hamid Mutapčić, PhD, Faculty of Law, University of Tuzla, B\&H

Phone: 0038761374484

E-mail: hamid.mutapcic@untz.ba
} 
The basic intent of the Legislator is to contribute to the ordering and updating of the status of the land registries through new and high quality legislative solutions, which should in the end contribute to a faster and simpler legal transaction of real estate. One of such solutions is a new definition of the principle of trust in the land registry, which aims to provide for the protection of rights acquired on the basis of incorrect and incomplete land registry status, by which they depart for the long standing jurisprudence that permanently negated the application of this principle ${ }^{2}$. However, the question arises pertaining to whether a third conscientious person will enjoy such legal protection as a consequence of acquiring ownership rights or some other limited property right on real estate that is part of marital assets, whereby such real estate is recorded in the land registry as belonging to only one marital partner. ${ }^{3}$ In legal theory and jurisprudence the issue of validity of the legal relation regarding the sale and burdening of such real estate by the registered right holder is raised. Bearing in mind the fact that in our legal system the principle of causal tradition is applied, the taking of the correct position regarding this legal issue is of great significance.

\footnotetext{
${ }^{2}$ „Only by confidence in the land registry and the registration of the ownership rights in purchased real estate, a buyer can be considered to be in a stronger position in right opposed to the previous acquirer that is holding the real estate in possession, if toward him has come into power the basis for the acquisition of the right through adverse possession. A conscientious buyer of real estate is that person who, aside from investing trust in the land registry previously establishes the status of the possession of the purchased real estate." (Decision of the Supreme court of Serbia, Rev. 4740/92, Vuković, S., 2003). „Person who has the legal basis of the acquisition and the possession of the real estate has a stronger right from the owner of the right of ownership registered in the land registry" (Decision of the Supreme court of Vojvodina Gž. 103/89). "When in a law suit two rights on the same real estate emerge, whereby one is a land registry registered right and a right that is based on a judicial verdict, always the stronger in right will be the one in the possession of the property, by which one should appreciate the conscientiousness of the contractual party" (Decision of the Supreme court of Serbia, Rev. 120/80)

${ }^{3}$ In marital assets the property that the marital partners have acquires by their work during the marital communion enters, as well as any revenues from such property (Family law of the Federation of $\mathrm{B} \& \mathrm{H}$ (in the remainder of the text $\mathrm{PZ} \mathrm{FBiH}$ ) and the Family law of the Republic of Srpska (in the remainder of the text PZ RS)) according to PZ FBiH marital assets are treated as co-ownership, while according to the FL RS marital assets are treated as joint ownership.
}

Bearing in mind the fact that in our legal system the principle of causal tradition is applied, the taking of the correct position regarding this legal issue is of great significance. By merely registering, the right of ownership is not acquired if the underlying contract is not valid according to the rules of substantive law, and that is how the principle of the causality of the registration manifests. The registration of the right of ownership can only be executed if it is based on a valid contract on the sale of the real estate, or on some other contract that can be used as a basis for the transfer or property rights (gift contract, lifelong care agreement, exchange contract and other.) This means that the registration in the land registry is causally linked to the underlying legal relation by which the seller undertakes to assume the obligation to transfer the right of ownership of the real estate to the buyer, or by the legal relation by which some of the limited property rights on real estate are formed to benefit the acquirer (such as a mortgage or easement). ${ }^{4}$

${ }^{4}$ In legal systems that have adopted the principle of causal tradition, such as the Austrian, Croatian, Serbian and Montenegrin and even our own legal system, the protection of the trust is weaker as there exists the possibility that the registration can be voided due to the lack of validity of the underlying legal relation which is why conscientious acquirers of the real estate will be safe only after it has been established that the underlying legal relation is valid, on the basis of which the registration has been executed, or when the deadlines for a successful legal claim to erase the registration have elapsed. The deficiency of this principle is reflected by the fact that it diminishes the legal safety in the legal transfer or real estate, as it provides the possibility of the erasure of the ownership right that has been registered in the land registry on the basis of a voidable legal relation. In legal systems that have adopted the principle of the abstract tradition, such as the German legal system the protection of trust is more stringent, as there does not exist the possibility of fighting the registration on the basis of the voidability of the underlying legal relation. In such cases the idea is more thoroughly applied that the law should protect the conscientious acquirers of real estate that have placed their trust in the accuracy and the completeness of the land registry registration, which affects the process of the fixing and updating of the land registry status more strongly. The impact of the principle of causal and abstract tradition at the protection of principle of trust depends on the fact whether there exists the legal possibility to dispute the validity of the registration of a conscientious acquirer of real estate of his predecessor in title due to the non-existence or the voidability of the legal relation on the basis of which the registration was executed. Therefore the difference between the causal and the abstract tradition in regard to the protection of trust comes to the fore in those legal systems in which it is possible to demand the erasure or the correcting of the void registration of the predecessor in title. On the abstract tradition in German law see: Josipović, 1995, Tratnik, \& Vrenčur, 1999, broj 6-8 
Jurisprudence does not have a unique position on the issue of the validity of the sales contract or the burdening of the real estate by the marital partner that is registered in the land registry as the sole right holder of a property right. Different legal understandings generate the appearance of different judicial verdicts that diminishe the principle of legal certainty as one of the founding principles of the legal system of Bosnia and Herzegovina. This significantly burdens the legal transactions of real estate, which is not commensurate to the spirit of the total reform of the land registry law. This practice is not in line with the practice of the countries comprising the European union that apply the land registry system of registering real estate and rights regarding real estate. So, for example, it is known that the land registry in German law works flawlessly thanks precisely to the consistent application of the principle and the norms affirming the land registry and the application of the registration of the acquired rights on real estate. ${ }^{5}$ By analyzing judicial verdicts one can notice that in the application of the law there is still the call to the principle that no one can transfer on the other more rights than they themselves have, ${ }^{6}$ which is why the principle of trust in the land registry is relativized and why it practically disables its application.

${ }^{5}$ In German law for the acquisition of the registered right on the foundation of the principle of trust it is necessary to establish that the registration is requested against the person that had disposed of the registered right on behalf of the conscientious acquirer and which is registered in the land registry as the right holder of that particular right (Baur, 1978).

${ }^{6}$ Decisions of the Constitutional court of the Republic of Croatia no. U-III-493/2002 of the 13th of October of 2004 and no. UIII-103/2008 of the 14th of June, 2011. In the process of adopting new entity laws in the area of property and land registry law our Legislator had followed the legislative solutions, experience and jurisprudence of the Croatian legislator, and so in regards to the regulation of the principle of trust in the accuracy and the completeness of the land registry. Bearing in mind the evident influence of the Croatian land registry and property law at our legal system it is desirable to familiarize oneself with the content of the cited judicial verdicts, so as to point out to all the issues and misunderstandings in the application of the law. It is for that reason that in the remainder of the work the analysis of the Decisions of the Constitutional court of the Republic of Croatia will be carried out regarding the verdicts that resolve legal disputes arising from the disposition of marital assets by the persons that are registered as sole right holders of the right of ownership. This applies to the cases in which the court had decided on the acquisition of property rights that had occurred after the coming into effect of the new land registry and property law of the Republic of Croatia. This is due to the reason that one can clearly notice the continuity in the method of solving the ownership disputes of this kind, regardless of the fact that the Legislator had redefined the principle of trust and had thus disallowed the appearance of the legal position that had dominated the jurisprudence in the countries of former Yugoslavia.
One should have in mind that the earlier Yugoslovenian jurisprudence, in the lack of legal solutions, and on the basis of the aforementioned principles, had altogether too broadly set the subject of research and investigation on the part of the later acquirer of the real estate (from the conscientious acquirer the investigation was demanded and not only of the land registry but also of the possessive state of the real estate) and this has disabled the conscientious acquiry of the registered person ${ }^{7}$. Aside from the low quality and inconsistent legal solutions contained before all else in the Law on property legal relations (in the remainder of the text ZOSPO) and later in the Law on ownership legal relations (in the remainder of the text: $\mathrm{ZOVO})^{8}$, jurisprudence is pointed out as the primary cause of the destabilization of the land registry and for the abandonment of the registering of legal transactions for real estate.

In the goal of the proper understanding of the principle of trust, and honoring the intention of the creator of the new Land registry an property law, in the remainder of the paper we will indicate the fundamental difference between the originary and the derivateive right acquiry methods, as well as the reasons why jurisprudence has permanently negated the application of the principle of trust. Only in the context of these questions is it possible to assume the appropriate attitude regarding the validity of contract on the dispossession and the burdening of real estate by the marital partner that is registered in the land registry as the sole right holder of the ownership right.

\footnotetext{
${ }^{7}$, The acquirer of real estate will be considered conscientious if during the acquisition of the real estate he had established that the transferor had been in possession in fact of the transferred real estate. It is not enough to merely review the land registry and the cadastral deed to establish the answer to the issues of possession" (Decision of the Supreme court of Vojvodina, Rev. $525 / 65$, cited in Orlić, 2/1980) „The buyer has an obligation during the purchase to verify not only on the basis of inspection of the land registry who the owner is, but also in the nature (in the field) who possesses the real estate." (Verdict of the Supreme court of Vojvodina, rev. 272/89, cited according to Stamenković, 1991)

${ }^{8}$ Until the coming into power of the ZOSPO the principle of registration was ordered by the legal rules of land registry law in a manner that all registry rights could be acquired, transferred, limited or be disposed of only through the registration in the land registry. According to the ZOSPO the registration had created a constitutional application only in the cases where the property right on the real estate had ben acquired on the basis of a legal relation. In all other cases the registration in the land registry only had a declarative effect. The identical legal solution had been ordered in the ZOVO.
} 
THE BASIS OF THE CONTRACTUAL OBLIGATION OF THE SELLER AS A PRESUMPTION OF THE DERIVATIVE RIGHT ACQUISITION

Correct (true) and up to date records on the rights regarding real estate is a presumption of unhindered legal transactions, especially in the case where the acquirer derives his or her right from the right of the predecessor (derivative right acquisition). With the derivate right acquisition the person transferring the right must be the real land registry owner for the buyer to acquire the right of ownership by registering in the land registry on a particular real estate. When the acquisition of the right of ownership on real estate is on the basis of a legal relation, then the rule that no one can transfer more rights on the other than they themselves have (nemo plus iuris ad alium transfere potest quam ipse habet) applies. In the cases that the seller is not the real owner of the real estate, then the sales contract will be void due to the nonexistence of the basis for the contractual obligation of the seller. This rule applies without exception in the derivative right acquiry method.

However, during the acquisition of property rights on real estate on the basis of the principle of trust in the land registry the ownership of the predecessor is not a substantive prerequisite for acquisition. This is due to in this case ownership not being derived from the ownership of the predecessor but is acquired originally, on the basis of the actual legal norm (originary right acquisition). Even though there is no basis for contractual obligation of the seller, the contract will be valid. With the originary right acquisition method the basis of the contractual obligation is not the general condition of validity of the legal relation, because the acquirer has derived its right from a person who is not the owner through the protection of the trust in the accuracy of the land registry. Conscientious acquirer by calling on the originary right acquiry method has compensated for the nonexistence of the basis of the contractual obligation, because even then a fully valid legal relation, independent of what constitutes the basis of the contractual obligation, is the foundation of the legal relation as a legal basis. It is enough that the person disposing of the right in the land registry is marked as the owner of real estate, and it is not necessary that said person be the actual owner of said real estate, considering that the legal effects of the protection of trust fixes the nonexistence of the authorization of the registered prior owner to dispose of the existing registered right, because the conscientious acquirer is protected, who, by trusting in the accuracy of the land registry had considered that the registered prior owner is the actual owner (Mutapčić, 2016). The unchanging presumption that the registered prior owner is the actual right holder of the registered right and that he or she is able to dispose of said right functions to the benefit of the conscientious acquirer. Therefore the conscientious acquirer, that had relied on the principle of protection of trust in the accuracy and completeness of the land registry will, through registration acquire property rights even though it was not registered in the land registry to benefit its actual owner, or rather regardless that the seller, for whose benefit it was registered, was its actual right holder (Mulabdić, 2007).

\section{CONCIENTEUSNESS AS PRESUMPTION OF VALID DISPOSETION OF MARITAL ASSETS}

The key presumption of validity of a legal relation, on the basis of which the seller transfers the right of ownership to the buyer, in circumstances when the land registry status does not match the actual status regarding the real estate is the conscientiousness of such an acquirer. The same rule applies in cases of disposition of real estate that is the subject of marital assets by the marital partner that is registered in the land registry as the exclusive ownership right holder (Korać, 2009). If the acquirer is conscientious then the contract will be valid no matter the fact that the transferor is not the actual owner of the real estate. If the opposite is the case the contract will be void, which will affect the voidability of the registry that might have been done to benefit the acquirer. For the existence of conscientiousness familiarization with the registered status of the real estate and the lack of knowledge of the extra-land registry status that exist to benefit some other person is necessary (Mutapčić \& Brkić, 2015), in this case to benefit the marital partner that had not been registered in the land registry as the right holder. Therefore, the acquirer will be conscientious if he did not know nor could he know that the land registry state is incorrect or is incomplete, which means that there exists a legal obligation of research of not only the registered but also of the extra-registered status of the real estate in question (ZSP FBiH/RS).

The nonbinding of the acquirer to research of the extra-registered status of the real estate does not exclude the possibility of proving its conscientiousness, if her or she, considering the circumstances of the actual case, knew or could have known that the land registry status is incorrect or incomplete (LR FB\&H/RS). 
However, the question of whether the acquirer will be conscientious if he or she knew that the seller is married to a person, which could indicate to the conclusion that the real estate is part of marital assets. We consider that the presumption of conscientiousness is satisfied even in circumstances when the acquirer knows that the transferor is in matrimonial union. If the opposite were true, if that fact would be qualified as a sufficient reason to demonstrate doubt in the accuracy and the completeness of the land registry, then in that case this would fundamentally change the principle of trust as a new originary right acquiry method for property rights in these circumstances. Such an understanding would not be in line with the needs of the modern legal system. Namely, if the acquirer, at the moment of conclusion of the legal relation, had to establish whether an object of the contract is marital assets or not, than this would considerably slow down the legal transfer or real estate. Such an understanding would also not be in line with the intent of the legislator that the lack of good faith can be transferred to someone merely because such an individual did not investigate the extra-registry status of the real estate (ZSP FBiH / RS) Based on this but also other legal solutions that treat the principle of trust one can notice that the basic intent of the legislator was to place the principle of trust to the forefront, by which the long standing jurisprudence that had previously permanently negated this form of property right acquiry is ended. "The intent of the legislator is to reduce the extra-registry acquisition would have to mean that the exploration of the extra-registry state cannot any more be considered as a condition for conscientiousness" (Povlakić, 2009). In any case it is a well-known fact that the land registry state of the real estate in the largest number of cases does not fit the actual state, which is why this fact too can have an influence to the un-conscientiousness acquisition. It is precisely due to this understanding in the previous jurisprudence that had not allowed the acquisition of property rights on real estate from a person who is not the owner, which has led to general doubt in the land registry and its contents. However, the land registry performs it function precisely in circumstances where it is not in line with the possession status of the real estate, which is in the process of reform of the Land registry law has led to the promotion as a fundamental rule in the form of its basic principles.
Therefore each circumstance that can lead the acquirer in the state of doubt regarding the truth of the land registry state, and which necessarily means the active investigation of facts that exist outside of the land registry, as is the case with the fact that the registered right holder has entered into matrimonial union, is not in line with the content of the norms that consider such investigation of the extra-registry status of real estate no longer as the condition for conscientiousness, and is not in line with the intent of the legislator directed in the heading of creation of presumptions for a stable and effective land registry. ${ }^{10}$

Unconscientious acquisition exists only in the case when the acquirer knows or can know that the other marital partner is co-authorized regarding the rights on the real estate that is the subject of the disposition or of the burdening.

${ }^{10}$ Previously we had mentioned that in German law there is a high rate of accuracy of the land registry largely thanks to the consistent application of the principles and norms that affirm the land registry and to the application of the registrations of acquired rights on real estate. Conscientiousness in regard to the extra or non-registry status of the is absolutely irrelevant, considering that the acquirer is required to examine only the land registry status of the real estate (Baur, 1978). In the German legal theory the understanding that the acquirer will be conscientious even when his or her lack of knowledge in regards the possessive state of the real estate is a consequence of gross negligence is dominant, or rather, if the acquirer during the acquisition of some right regarding real estate had not paid a given amount of attention in regards to the investigation of the accuracy of the land registry that is expected from an averagely attentive person in legal transactions. To prevent conscientious acquisition on real estate aside from gross negligence, doubt or light negligence are also not sufficient. So the acquirer will be conscientious even in the case when he or she had doubted in the accuracy of the land registry data in regards the real estate he or she is acquiring or from negligence did not know of the existence of such facts (Weike, 2006, Stanković \& Orlić, 2001). This legislative solution in German law is interesting compared to the solution of this issue in our own legislature. According to the entity laws on property rights conscientiousness is required in regards to the familiarization of the land registry and to the lack of knowledge of the extra-land registry status of the real estate. The condition for the lack of knowledge of the extra-land registry state is fulfilled only if the acquirer did not know nor given the circumstances could have known that the land registry status is incorrect or incomplete, meaning that for the existence of conscientiousness it is enough that the acquirer did not know that the registered land registry owner had disposed of the real estate or had delivered it to independent possession to the buyer. It flows from that reasoning that the presumption of conscientiousness of the acquirer will not be fulfilled if he or she had on the basis of certain legally relevant facts, exiting outside of the land registry, still knew or had to know that the real estate did not belong to the seller. 
In that case the legal relation will not produce any legal consequence, so the potentially carried out registration to benefit the acquirer on the foundation of such legal relation will be canceled. This is due to the reason that the law does not allow acquisitions that are contrary to the principle of conscientiousness and honesty.

In legal theory there exists the understanding according to which the acquirer will be considered conscientious even in those circumstances when he or she knew that the real estate is a part of marital assets. This means that it is presumed by disposing of the real estate by the marital partner that is registered as exclusive right holder it is presumed that such a legal relation was acquiesced to by the other marital partner as well. So, the third person as acquirer starts of from the presumption that such a disposition was acquiesced to by the other martial partner, and said presumption flows from the communitive life of the marital partners (Korać, 2009). We consider this understanding unacceptable for the reason that the legislator protects only those acquirers that do not know or could not know that the land registry state, in regards to the real estates on which property rights are acquired, are incorrect or incomplete.

\section{PRINCIPLE OF TRUST IN INTERPRETING JURSPRUDENCE}

In the lack of the legislative solution prior Yugoslavian jurisprudence had permanently negated the application of the principle of trust. This position was founded on the thought that on the basis of the legal relation one cannot acquire the right of ownership on real estate form one who is not the owner, because no one can transfer more rights to someone else that he or she themselves do not have (the transferor must be the owner for his right of ownership to be able to be transferred to the acquirer). The reasons for these actions of the courts can be found in the status of the land registry, that it did not reflect the actual picture found in the legal records of real estates and current rights regarding real estate, as well as in the lack of quality in the legislative regulations that allowed for legal transfer of rights regarding property outside of the land registry. However, we should not forget the jurisprudence that, due to the existence of disharmonized verdicts, but also due to different interpretation of the legislative rules, had contributed to the destabilization of the land registry and tis fundamental principles.

\section{Land registry status of real estate}

In the older jurisprudence the legal understanding that one cannot acquire ownership or other limited property right from the person that was only the formal holder of the registered right was dominant. The courts appreciated that every later acquirer had to check the possessive state of the real estate, so as to make sure that the land registry transferor was its actual owner. This is due to the reason that often there was conflict of different legal bases for the acquisition, were more persons laid claim to the formation of exclusive ownership on the same piece of real estate. In legal disputes dealing with the conflict between the registered and the nonregistered owner of the real estate, the courts would give advantage mainly to the non-registered owner, on which we discussed previously. The reason for these actions of the courts should be sought in the status of the land registry, that did not reflect the actual picture in the legal records of the real estate and the actual rights on the real estate.

It is precisely due to such land registry status of the real estate that the jurisprudence had consequently demanded conscientiousness not only in regards to the registered but also to the extra-registered status, which means that every acquirer had an obligation to investigate the possession status of the real estate as well. If it later turned out that some other person before the disputed registration had acquired the property right on the property, that was not registered in the land registry, then it would burden the conscientiousness of the later acquirer, which is why they would mostly lose ownership lawsuits of this kind. In the conflict of rights between the registered and the extra-registered owner the advantage was given to the extra-registered owner of the real estate that had a stronger legal claim for the acquisition according to the substantive law. In jurisprudence this was justified in the manner that in those cases justice was paid attention to. However, this practice of the courts had a negative impact on legal certainty, because if the acquirer aside from the facts that are registered in the land registry must also pay attention to the facts that exist outside of the land registry, he or she will never be secure in the knowledge that some right on a piece of real estate is actual acquired, regardless that he or she had registered such a right, as there can always appear a third person claiming that it had the same piece of real estate in possession in the moment when the acquirer had acquired and executed the registration of the right to the same piece of real estate in the land registry. 
This understanding did not contribute to the fixing and the updating of the land registry status. On the contrary, the land registry were additionally destabilized, and extra-registry right holders were protected and demotivated to initiate procedures for the registry of extra-registry acquired rights.

It can be concluded that the disparity between the registry and the extra-registry status of the real estate is additionally contributed to by the jurisprudence by avoiding the application of the rules of Land registry law all under the excuse that the general legal circumstances (land registry records on rights in real estate are different from the actual status) were such that the principle of justice demanded this type of position. "The parallel actions of inconsequent application of the principle of registration, the possibility of extraregistry acquisition and the determination of conscientiousness that was built in the jurisprudence of former SFRY (conscientiousness was only the one who researched extra-registry state) has inescapably had as a consequence that the land registry that was not up to date" (Povlakić, 2009).

\section{Legislative framework}

Until the coming into power of the Law on property right relations the principle of registration was regulated in the rules governing land registry rights in quite the opposite way: "Land registry rights can be acquired, transferred, limited or terminated only through the registration in the land registry" (ZZK KJ) However, the legislator and the jurisprudence had gone in a different direction and had treated the registration as a legal means of acquiry only with the acquiry based on legal relations, while in all other cases the registration of the acquired right in the land registry only had a declarative effect (ZOSPO). The identical solution was taken in the ZOVO, as in the Law on ownership and other property rights of Brčko Disgrict B\&H. The lack of obligation of registration of such rights had led to the fact that it exclusively depended on the will of the right holder of a registered right if the registration against the registered person were to take place, which would most often not be done due to negligence or avoidance of payment of registration obligations (Babić, 2011).
Even though LLR FB\&H / RS regulate that the property rights on real estate are acquired exclusively by registering to the land registry ${ }^{11}$, except in cases of inheritance, which represents the difference between the ZOSPO and the ZOVO, the solution of the ZSP $\mathrm{RS} / \mathrm{ZSP} \mathrm{FBiH}$ mean a return to the solutions that were known in ZOSPO and ZOVO because they regulate that the acquirer or the right of ownership that was acquired based on the law, inheritance, a valid court verdict or the final verdict of some other relevant government body, is authorized to demand the registration of such a right in the land registry. It follows that the possible acquisition of the rights of ownership and other property rights even without registration in the land registry are possible, which was the positon of the previous property rights as well. It is obvious that there exists a disharmony between the land registry and property law in this regards. However, the laws that regulate property and real estate law must be in harmony, especially when the registration as a legal method of acquiry of property rights in real estate is on the line. It is necessary in the forthcoming timeframe to execute the harmonization of the rules of both the land registry and property law so as to shed light on all possible misunderstandings and doubts in the application of the law and to prevent the appearance of different legal positions in jurisprudence (Mutapčić, 2016). If the jurisprudence would apply the rules of ZZK FBiH/RS consistently, it would considerably diminish the possibility of extra-registry acquisition of rights in real estate, which would contribute to the harmonization of land registry and the possession status of real estate. It could be concluded that this is the basic intention of the creator of the land registry law and so it is necessary to harmonize rules of both the land registry and property law in this regard.

\footnotetext{
${ }^{11}$ The goal of this rule, which signifies the breaking with the up to now legal tradition, is to limit the possibility of extra-registry acquisitions of registry rights for the reason that exactly that kind of acquiry generate the appearance of the messed up land registry state. „The breaking is done with the goal of protecting the contentious acquisition by a third person on the basis of the legal relation and to sanction the missing of the registry of the extraregistry acquired rights by their holders“" (Mulabdić, 2007)-
} 
By negating the principle of trust in the truthfulness and the completeness of the land registry in jurisprudence the position that was represented was the one of the rules of ZOSPO regarding the acquisition of the ownership right from the person who is not the owner on the basis of the legal relation can only relate to the acquisition of ownership on movable things, while from the person who is not the owner one cannot acquire the right of ownership on real estate, no matter the conscientiousness of the later acquirer. ${ }^{12}$ In the lack of the legislative solution the jurisprudence had permanently negated the application of the principle of trust, by all the while emphasizing as the primary reason the protection of extra-registry acquired rights to benefit their right holders. If by these understandings, which were dominant in the previous Yugoslav jurisprudence, the fact that ZOSPO and later ZOVO, demanded registry only in the case when property rights on real estate were acquired on the basis of legal relations is taken into effect, than it is perfectly understandable why the land registry no longer has the significance it had according to the previous ZZK KJ. It is to expect that the new definition of the principle of trust in land registries will generate a different jurisprudence, because the nonobligatory research of the extra-registry rights status of real estate will stabilize the land registry and will make the legal transfer or real estate simpler and faster. The Supreme court of FB\&H has already ruled on one significant verdict on the basis of art. 9 of the ZZK, by which in a completely new way conscientiousness and the principle of trust is valued, which represents the breaking with current judicial practice (Supreme court of FB\&H verdict, Rev. 530 P 006550 from the 14th of February, 2013).

\footnotetext{
„12,On the basis of a legal relation - sales contract from a person who is not the owner one cannot acquire ownership even according to the rules of property law - paragraph 367 OGZ. According to article 31. Law on property law relations for derivative acquisition of ownership a prior owner is necessary, and the acquisition form a non-owner is possible only on moveable objects" (Decision of the Supreme court of Croatia, Rev. 1816/89 of the 1st of March, 1990) „Buyer of a real estate does not have legal title to register the ownership right if the seller was not the owner, nor did the buyer acquire ownership through adverse possession, if the real estate were confered to the person that had acquired them previously at a public auction in the executive procedure" (Verdict of the Supreme court of FB\&H, Rev. $26 / 88$ of the 17 th of September 1988). ,According to the legal rule of paragraph $367 \mathrm{Biz}$. OGZ by buying from a non-owner at a public sale (auction) one can acquire ownership only on a moveable thing and not on an immoveable thing" (Decision of the County court Split, Gž. 1489/77 of the 27th of April, 1979) „By buying an immoveable thing form a person who is not the owner one does not get the ownership of the thing. Opposed to the real owner the buyer does not benefit that he bought the thing and had taken possession in god faith that was acquired from the owner." (Decision fo the Federal Supreme Court Gz. 6/57 of the 15th of February, 1957. Collection of judicial verdicts (1957) Book II. Binder I. Belgrade).
}

\section{APPPLICATION OF THE PRINCIPLE OF TRUST IN NEWER JURISPRUDENCE AS A RESULT OF DISPOSITION OF MARITAL AS- SETS}

By coming into effect of the new Entity laws on land registries the long standing jurisprudence is abandoned, which should not be judged negatively. From the extra-registry property right holders on real estate a more responsible relation to their acquired rights is demanded under the penalty of their loss of rights by the action of legal effects of the principle of trust in the land registry. The law protects conscientious acquirer by third persons, and sanctions the failure to register extra-registry acquired rights by their holders. However, through the analysis of court verdicts one can notice the continuity in the method of decisions and resolutions of ownership disputes of this kind, no matter the fact that the legislator had redefined the principle of trust and had discontinued the appearance of legal positions that were dominant in the earlier Yugoslav jurisprudence. So in the decision of the Supreme court of the Federation of B\&H number: 65 0 P 04969112 Rev, of the 29th of August, 2013 it is pointed out that the legal relation on the basis of which one marital partner had disposed of marital assets without the consent of the other marital partner is not valid in the light of rule art. 103 par. 1 of the Law on obligation relations (in remainder of the text ZOO) as it was concluded contrary to the imperative legal norm in art. 265 of the former Family law of the Federation of B\&H. In the same reason the County court in Zadar in verdict no. Gž 52/99 of the 27th of November of 2001 had rejected the appeal of a buyer that had argued acquisition of ownership rights on the basis of the principle to trust in the land registry. The Municipality court in Zadar, as the court of first instance in a civil procedure had decided regarding the law suit to erase the recording of the right that was filed by the wife against a husband who was a seller and a third person that had relied on the accuracy of the land registry record, and on the basis of the sales contract had performed the recording of the acquired right in the land registry.

\footnotetext{
${ }^{13}$ In the revision procedure the Supreme court of the Federation of $\mathrm{B} \& \mathrm{H}$ ha decided on the property right that was acquired prior to the coming into effect of the new land registry and property law.

${ }^{14}$ The redefinition of the principle of trust in Croatian law was done by the coming into effect of the Law on land registry of the Republic of Croatia 8in remainder of the text ZZK RH ) and ZV RH
} 
This was done for the reason that in the land registry as the owner of the real estate in question before the disputed registration, the registered right holder was the husband only. However, the plaintiff had demanded for it to be established that the house in question was communal property of both her and of the first respondent acquired in matrimony, and for it to be established that the sales contract between the first respondent and the second responded was void, and due to all that for the court to order the erasure of the right of ownership of the second responded and to record communal property of the plaintiff and the first responded. That is how the County court in the verdict no. 530/98 of the 17th of November, 1998 had accepted the legal claim and had stablished that the sales contract on the basis of which the third person had performed the registration of the right in his or her benefit was not void and had acceded to the claim to order the erasure of the registration of the right of ownership of the seller and to file the right of communal ownership which was confirmed in the cited verdict of the County court in Zadar as the court of the second instance. However, the acquisition of the disputed right to benefit the second responded had happened before the coming to effect of the $\mathrm{ZV} \mathrm{RH}$, which in the rule in art. 123 had predicted the possibility of acquiry of property rights on real estate on the basis of incorrect and incomplete land registry. In the same law it had been foreseen that the solution toward the issue of acquiry change legal effects and the ending of property rights up until its coming into power are to be decided on the rules that were applied in the moment of acquisition, change, or the ending of the right and its legal effects. This means that regarding the issues of the cited dispute it was argued and disputed according to the rules of the Law on basic ownership legal relation that had not foreseen the acquisition of property rights on the basis of the principle of trust in the land registry.

However in ownership disputes of this kind, that had appeared as a result of acquisition on the basis of the principle of trust that is regulated in the new land registry and property rights of the Republic of Croatia the courts have made almost identical decisions. In such decisions the principle of trust in the land registry is again relativized, and the advantage to extraregistry right holders of property rights is given to the detriment to contentious acquirers who, relying on the accuracy and the completeness of the land registry had completed the registration of their acquired rights (decision of the Constitutional court of the Re- public of Croatia no: U-III-493/2002 of the 13th of October, 2004 and no: U-III-821/2007 of the 20th of June, 2008) The reason for the adoption of such decisions lies in the fact that it is still the practice to not deviate from the principle that no one can transfer on the other more rights than they themselves have, no matter that in this case it is about a new originary right acquisition method where ownership of the predecessor is not a material presumption for valid acquisition, as well as for the understanding that the disposition by the registered marital partner is not valid in the sense of the rule art. 103 par 1 of the $\mathrm{ZOO}$ which was confirmed in the previously cited verdict by the Supreme court of the Federation of B\&H.

Cited legal understandings in our and Croatian law that relate to the establishment of voidness of the legal relation on the disposition of martial assets by the registered person are not the result of the existence of a clear and precise rule that would indicate to such. On the contrary in the new land registry and property rights law of B\&H solutions have given that, without any doubt, provide protection to the trust in the land registry to benefit third persons, no matter that this could result in the loss of a great number of extraregistry acquired rights. Anyway, the intention of the legislator was precisely the reaffirmation of the land registry in a method and a way that it should finally fulfill its function and even in circumstances when the land registry stat of the real estate does not match the real state. These understandings are, "unfortunately, the result of multi-decade jurisprudence that had permanently negated this method of acquiry of property rights on real estate, and in this way had further contributed to the destabilization of the land registry. The interpretation of the principle of trust is expressed in the jurisprudence before the coming into effect of the new land registry and property rights is understandable, considering that the legal solutions, contained in the previous property rights law had made possible the legal framework for such action of the courts, what with the existence of clear and precise legal rules that widened the circle of exception to the principle of registration and the principle of trust, what with the existence of legal loopholes in certain areas. A typical example of this other one is the understanding that had appeared regarding the definition of the principle of conscientiousness and the subject of the research of the later acquirer of the real estate, which is a consequence of the lack of existence of a clear and precise legal rule in one very important issue. 
However, this practice is not acceptable, especially after the legal redefinition of the principle of trust in accuracy and the completeness of the land registry had been done. The ending of the extra-registry acquired rights should be understood as a sanction toward negligent and inert extra-register right holders of such rights that did not demand their registration in the main land registry, and is in no way an obligation of the legislator with the goal of their preservation. It is for that reason, in legal disputes in which debate is had and decisions are made between the land registry and extra-record rights on the same real estate that the courts should have in mind the intent of the legislator and of the entire reform of the land registry law system, whose goal is the reaffirmation of the status of the land registry and the harmonization of the land registry and possessive status of the real estate" (Mutapčić, 2016).

In the jurisprudence of the countries of former Yugoslavia other legal positions have been recorded. In the decision of the Supreme court of Slovenia, resolving the legal dispute due to the disposition of the real estate by a martial partner that was registered in the land registry as a formal right holder, the advantage was given to the rules of the land registry law, or rather to the principle of trust in the accuracy of the land registry over the rules of the family law, according to which the lower court had established the voidness of the contract and the registration in to the land registry to benefit the third person. The Supreme court had resolved the case in which as the land registry recorded owner was only one of the martial partners who was registered, and in the procedure of the executive remuneration against said marital partner the real estate was sold to the third person. The other marital partner had filed a claim against the third person and the marital partner demanding the cancelation of the contract on the disposition of the real estate and the establishment of the ownership right over the real estate to her benefit. The court of first instance had ruled in her favor and had cited the Law on marriage and familial relations of Slovenia from 1989. This court had established that the communal property on the real estate was an object of marital assets and had decided that the legal relation and the registration transferring the ownership right on the piece of real estate to benefit the third person were void. The court of second instance had overruled the court of the first instance and had rejected the claim of the plaintiff. The Supreme court of Slovenia had rejected the revision filed by the plaintiff as unfounded and had confirmed the second instance verdict. Due to the significance in the continuation we cite some of the legal positions found in the cited decision of the $\mathrm{Su}-$ preme court of Slovenia: " in the cited legal matter one should carefully weigh the different interest $\mathrm{s}$ of the parties (one of the sides most certainly is the protection of property interests of the damaged marital partners, while the other is the interest of the protection of the individual who had bought the piece of real estate trusting the land registry); in the conflict of the regulations of Family law and the Law on land registries the advantage should be given to the Law on land registries that protects the efficacy and the security of the legal transactions as a legal-political value of the higher level and significance; that in addition to such an objective reason in addition to rejecting the plaintiffs claim (the one of the wronged martial partner) speaks also a subjective reason: that the plaintiff herself had failed to register her communal property in the land registry and has failed to prevent the disposition of the other marital partner; that the party (the plaintiff) due to her personal inactivity and negligence had not in the land registry registered a right that she could have registered, cannot then through this type of lawsuit demand the finding of the execution not being allowed at "her" part of the communal property, and all considering that the third person had acted in a fair manner and had acquired his or her property in one of the ways that had been foreseen by this law" (Decision of the Supreme court of the Republic of Slovenia no: II Ips 253/2000).

Identical legal opinion was taken by the Supreme court of Serbia in the decision solving a similar legal dispute (Decision of the Supreme court of Serbia, Rev. 2981/05 of the 6th of September, 2006, Selection of jurisprudence number: 4/2008) In the explanation of this decision among others there is written: "In numerous real estate sales contracts or in the conclusion of legal relations on the burdens placed on real estate, as contractual parties there appear individuals who are married, and in those instances it is a rare occurrence that both marital partners are registered in the land registry as co-owners or communal owners. Therefore it follows that in these cases the nonregistered martial partner can challenge the contract concluded without his or her written agreement. This would result in the slowing down of the legal transactions and to seriously question the principle of legal certainty. This is true in particular due to the reason that the non-registered marital partner can be sued by the other partner who had sold the real estate or had burdened it, having changed their mind, and how through the law suit of the non-registered marital partner, and in collusion, exhibiting his or her dissatisfaction with the contract and hoping to attain the goal they on their own could not attain." 


\section{CONCLUSION}

By coming into power of the new entity laws on land registries a new definition of the principle of trust is introduced, which deals with the protection of the rights acquired on the basis of incorrect or incomplete land registry state. However, in the application of the law there does not exist a unique position regarding the application of the principle of trust in the cases of the disposition of martial assets by a marital partner that is registered in the land registry as the exclusive ownership right holder. In legal theory and jurisprudence the issue of the validity of the legal relations on the disposition or the burdening of such real estate by the registered person is actualized. This is due to the fact that the registered person is not the actual owner of the real estate, and according to some understanding, such disposition is legally qualified as not being allowed due to the non-existence of the basis of the contractual obligation of the seller. In this way the principle of trust in the land registry is actuated and given advantage over the extra-registry property right holders over conscientious acquirers who, relying on the accuracy and the completeness of the land registry had executed the registration of their acquired rights. The reason for the adoption of such decisions lies in the fact that there still is no deviation from the principle that no one can transfer on the other more rights than they themselves have, no matter the fact that in this case there is a new originary right acquisition method where the ownership of the predecessor is not the substantive presumption for valid acquisition. These understandingts are, unfortunately, the result of multi-decade jurisprudence that had permanently negated this method of acquisition of property rights on real estate and in that way had additionally contributed to the destabilization of the land registry. However, this practice is not acceptable, especially after the legal redefinition of the principle of trust in the accuracy and the completeness of the land registry had been executed.

During the acquisition of property rights on real estate on the basis of the principle of trust in the land registry, the ownership of the predecessor is not a substantive presumption for the acquisition for the reason that, in that case the ownership, is not derived from the right of the predecessor but is acquired directly on the basis of the law itself. This reflects the basic difference between the derivative acquisition and the acquisition based on the principle of trust in the land registry as an originary right acquisition method. With this form of acquisition the basis of the contractual obligation of the seller is not the general condition for the validity of the legal relation. The conscientious acquirer by calling on the originary acquisition method compensates for the nonexistence of the basis of the contractual obligation, which is why the fully valid legal relation, independent of what the basis of the contractual relation is the foundation for the legal relation as a legal basis. Therefore the conscientious acquirer, that had acted on the basis of the principle of trust in the accuracy and the completeness of the land registry, through registration will acquire the ownership right on the real estate, even though it was previously recorded to benefit the marital partner that was not the exclusive right holder of such a right. The same legal effects come into effect in the case of conscientious acquisition of some limited property right on real estate.

The law protects the conscientious acquisition by third persons, and sanctions the failure to record extra-registry acquired rights by their holders. In this way the affirmation of land registry principles is contributed to in particular the principle of registration, which will generate the harmonization of the land registry and the extra-registry status of real estate, and will speed up the legal transaction regarding real estate, and make it simpler. It is for those reasons in legal disputes in which it is discussed and decided on the conflict between the land registry and the extra-registry right over the same piece of real estate the courts must keep in mind the intent of the legislator and the total process of reform of the land registry rights, whose goal is the reaffirmation of the land registry and the harmonization of the land registry and the possessive state of the real estate.

\section{REFERENCES}

Babić, I. (2011). Komentar Zakona o stvarnim pravima Republike Srpske (Commentary of the law on property rights of the Republic Srpska). Privredna štampa. Sarajevo. 799.

Baur, F. (1978). Lehrbuch des Sachenrechts. München. 133-140, 145.

Josipović, T. (1995). Sustavi publiciranja prava na nekretninama kao temelj zaštite povjerenja u pravnom prometu (Systems of publication the right over real estate as a foundation for the protection of trust in legal transactions). Zagreb. $39-46$.

Korać, V. (2009). Pouzdanje u katastar nepkretnosti i raspolaganje zajedničkom imovinom (Confidence in the land registry and disposition of communal property). Pravni život 11. Beograd. 649-651, 654-655.

Mulabdić, S. (2007). Sticanje prava vlasništva dosjelošću s posebnim osvrtom na rješenja Zakona o zemljišnim knjigama (Acquisition of ownership rights through adverse possession with special attention given to solutions in the Law on land registry). Pravna misao 7-8/2007. 67. 
Mulabdić, S. (2007). Sticanje prava vlasništva na nekretnini polazeći od načela povjerenja $u$ istinitost i potpunost zemljišne knjige (Acquisition of the ownership right on real state from the bassi of the principle of trust in the accuracy and the completeness of the land registry). Pravna misao $7-8.42$.

Mutapčić, H., and Brkić, E. (2015). Uloga i značaj načela savjesnosti u procesu reforme zemljišnoknjižnog prava (Role and significance of the principle of conscientiousness in the process of reform of the land registry law). Zbornik radova Pravnog fakulteta $u$ Tuzli 1/2015. Tuzla. 23-25.

Mutapčić, H. (2016). Principle on the land register in the interpretation of jurisprudence. Human.

Odluka Okružnog suda (Decision of the District court) Split, Gž. 1489/77 od 27. IV 1979.

Odluka Vrhovnog suda (Decision of the Supreme court) BiH, Rev. 26/88 od 17. XI 1988.

Odluka Vrhovnog suda Hrvatske, Rev. 1816/89 od 01. III 1990.

Odluka Vrhovnog suda Republike Slovenije number: II Ips 253/2000.

Odluka Vrhovnog suda Srbije, Rev. 120/80.

Odluka Vrhovnog suda Srbije, Rev. 4740/92.

Odluka Vrhovnog suda Vojvodine, Gž. 103/89.

Odluka Vrhovnog suda Vojvodine, Rev. 272/89.

Odluka Vrhovnog suda Vojvodine, Rev. 525/65.

Odluka Županijskog suda (Decision of the County court) u Zadru number: Gž. 52/99, od 27. 11. 2001.

Odluke Ustavnog suda (Decision of the Constitutional court) Republike Hrvatske br. U-III-493/2002 od 13. Listopada (October) 2004. i br. U-III-103/2008 od 14. Lipnja (June) 2011.

Odluke Ustavnog suda Republike Hrvatske number: U-III-493/2002 od 13. Listopada (October) 2004. i number: U-III-821/2007 od 20. Lipnja (June) 2008.

Orlić, M. (1980). Savesnost pri sticanju nepokretnosti (Conscientiousness at the acquiry of real estate). Pravni život 2/1980. 74 .

Porodični zakon FBiH (Family law of FB\&H) (Službene novine FBiH number: 35/05). Sarajevo, 2005. Art. 251. par. 1., 252. par. 2.

Porodični zakon Republike Srpske (Family law of Republic Srpska) (Službeni glasnik RS number: 54/02 i 41/08). Banja Luka, 2002. Art. 269. par. 5., 270. par. 5.

Povlakić, M. (2009). Transformacija stvarnog prava u Bosni i Hercegovini (Transformation of property law in Bosnia and Herzegovina). Pravni fakultet. Sarajevo. 119.

Povlakić, M. (2010). Načelo upisa i stjecanje prava vlasništva na nekretninama prema novom zemljišnoknjižnom i stvarnom pravu u $\mathrm{BiH}$ (Principle of registration and acquisition of the ownership right on real estate according to the new land registry and property rights law in B\&H). Godišnjak Pravnog fakulteta u Sarajevu LIII/2010. 322.

Presuda Vrhovnog suda FBiH (Verdict of the Supreme court of FB\&H), Rev. 530 P 006550, od 14. 02. 2013.

Presuda Vrhovnog suda Federacije BiH br. 650 P 04969112 Rev, od 29. 08. 2013.

Stamenković, D. (1991). Priručnik za upise u zemljišnu knjigu i katastar nepokretnosti. Savremena administracija (Manual for the registration in the land register and the cadaster of real estate). Beograd. 59.

Stanković, O., and Orlić, M. (2001). Stvarno pravo - deveto izdanje (Property law - Ninth edition). Nomos. Beograd. 334.

Tratnik, M., and Vrenčur, R. (1999). O sistemu abstraktne ter kauzalne tradicije v stvarnem pravu. Ljubljana. Pravnik number: 6-8. 99
Vuković, S. (2003). Sudska praksa iz svojinskopravnih odnosa (Jurisprudence in property law relations). Poslovni biro. Beograd. 264.

Weike, J. (2006). Značaj načela upisa i javnog povjerenja u zemljišnu knjigu shodno novom zemljišnoknjižnom pravu u Bosni i Hercegovini (Significance of the principle of registration and public trust in the land registry according to the new land registry law in Bosnia and Herzegovina). Zbornik radova Aktualnosti građanskog i trgovačkog zakonodavstva i pravne prakse. Pravni fakultet Sveučilišta u Mostaru. Mostar. 447.

Zakon o obligacionim odnosima (Law on obligation relations) (Službeni list SFRJ number: 29/78, 39/85, 45/89, 57/89, Službeni list RBiH number: 2/92, 13/94 i Službene novine FBiH number: 29/03). Beograd, 1978. art. 103. par. 1.

Zakon o osnovnim vlasničko pravnim odnosima Republike Hrvatske (Law on the basic ownership legal relations of the Republic of Croatia), Narodne novine br. 53/91, 9/92 i 77/92.

Zakon o stvarnim pravima Federacije $\mathrm{BiH}$ (Law on the property rights of the Federation of $\mathrm{B} \& \mathrm{H}$ ) (Službene novine $\mathrm{FBiH}$ number: 66/2013). Sarajevo, 2013. art. 52. par. 1., 55. par. 2. i $3 ., 316$.

Zakon o stvarnim pravima Republike Srpske (Law on the property rights of the Republic Srpska) (Službeni glasnik RS number: 124/08, 58/09 i 95/11). Banja Luka, 2009. art. 52. par. 1., 55. par. 2. i $3 ., 304$.

Zakon o svojinsko pravnim odnosima (Law on the property rights relations) (Službeni list SFRJ number: 6/1980). Beograd, 1980. art. 33., 58. i 69.

Zakon o vlasničko pravnim odnosima (Law on ownership rights relations) (Službene novine FBiH number: 6/98, 29/03). Sarajevo, 1998. art. 38.

Zakon o vlasništvu i drugim stvarnim pravima Brčko Distrikta BiH (Law on ownership and other property rights of the Brčko District) (Službeni glasnik Brčko Distrikta $\mathrm{BiH}$ number: 11/01 i 08/03). Brčko, 2001. art. 36. par. 1.

Zakon o vlasništvu i drugim stvarnim pravima Republike Hrvatske (Law on ownership and othr property rights or the Republic of Croatia) (Narodne novine number: 91/96, 68/98, 137/99, 22/00, 73/00, 129/00, 14/01, 79/06, 141/06, 146/08, 38/09, 153/09 i 143/12). Zagreb, 1996. art. 11. par. 1. i 2., 122., 123., 388. par. 2.

Zakon o zemljišnim knjigama Federacije $\mathrm{BiH}$ (Law on the land registries of the Federation of $\mathrm{B} \& \mathrm{H}$ ) (Službene novine $\mathrm{FBiH}$ number: 58/2002, 19/03 i 54/04). Sarajevo, 2002. art. 5.

Zakon o zemljišnim knjigama Kraljevine Jugoslavije (Law on the land registries of the Kingdom of Yugoslavia) (Službene novine Kraljevine Jugoslavije number: 146 - LIII od 1. jula 1930. i number: 281 XC od 1. decembra 1931. ). Beograd, 1930. paragraf 4. par. 1.

Zakon o zemljišnim knjigama Republike Hrvatske (Law on the land registries of the Republic of Croatia) (Narodne novine number: 91/96, 68/98, 137/99, 114/01, 100/04). Zagreb, 1996. art. 8.

Zakon o zemljišnim knjigama Republike Srpske (Law on the land registries of the Republic Srpska) (Službeni glasnik RS number: 74/02, 67/03, 46/04, 109/05 i 119/08). Banja Luka, 2002. art. 5 .

Zbirka sudskih odluka (Collection of judicial decisions) (1957). Knjiga II. Sveska I. Beograd. 156. 